\title{
Geographic and temporal patterns of non-lethal attacks on humpback whales by killer whales in the eastern South Pacific and the Antarctic Peninsula
}

\author{
Juan J. Capella ${ }^{1,2}$, Fernando Félix ${ }^{3,4, *}$, Lilián Flórez-González ${ }^{2}$, Jorge Gibbons ${ }^{5}$, \\ Ben Haase ${ }^{3}$, Hector M. Guzman ${ }^{6}$ \\ ${ }^{1}$ Whalesound Ltd., Lautaro Navarro 1163, Punta Arenas 6200000, Chile \\ ${ }^{2}$ Fundación Yubarta, Calle 34 Norte \# 2EN-55, Cali 760050, Colombia \\ ${ }^{3}$ Museo de Ballenas, Av. Enríquez Gallo S/N, Salinas, Ecuador \\ ${ }^{4}$ Pontificia Universidad Católica del Ecuador PUCE, Avenida 12 de Octubre 1076, Quito, Ecuador \\ ${ }^{5}$ Instituto de la Patagonia, Universidad de Magallanes, Avenida Bulnes 01855, Punta Arenas 6200000, Chile \\ ${ }^{6}$ Smithsonian Tropical Research Institute, PO Box 0843-03092, Panama, Republic of Panama
}

\begin{abstract}
The role and impact of killer whales Orcinus orca as predators of baleen whales has been emphasized by studies of humpback whales Megaptera novaeangliae. In this study, rake marks on the fluke were used as a proxy for predatory attacks in a sample of 2909 adult humpback whales and 133 calves from 5 breeding and 2 feeding locations in the eastern South Pacific and the Antarctic Peninsula. The goal of this study was to evaluate how often, at what age, where, and when humpback whales were more susceptible to attacks. Overall, $11.5 \%$ of adults and $19.5 \%$ of calves had rake marks on their flukes. Significant differences were found in the prevalence of scars in calves when comparing breeding $(9 \%)$ vs. feeding areas $(34 \%)\left(\chi^{2}=10.23, p<0.01\right)$. Multi-year sighting analysis of scar acquisition in 120 adults ( $82 \%$ site fidelity) and 37 calves in the Magellan Strait showed no new marks after the initial sighting for the subsequent 15 yr. This finding indicates that rake marks were most probably acquired when whales were calves, which supports the belief that scar acquisition is a once in a lifetime event. The odds of having rake marks increased with time but with a significantly higher rate in calves $\left(\chi^{2}=5.04, p<0.05\right)$, which suggests an increase in predation pressure over time. Our results support the earlier hypothesis that killer whale attacks occur mostly on calves, near breeding sites, and during the first migration to feeding areas.
\end{abstract}

KEY WORDS: Non-lethal attacks · Eastern South Pacific - Migration · Humpback whale · Megaptera novaeangliae $\cdot$ Killer whale $\cdot$ Orcinus orca $\cdot$ Rake scars

\section{INTRODUCTION}

Killer whales Orcinus orca are apex predators of marine megafauna, including large marine mammals (Morisaka \& Connor 2007). More than 20 species of cetaceans have been reported to be part of the killer whale diet (Jefferson et al. 1991, Durban \& Pitman 2012, Pitman \& Durban 2012). As regular prey of killer whales, cetaceans likely have developed behavioral strategies to reduce predation risk, such as becoming

${ }^{*}$ Corresponding author: fefelix90@hotmail.com silent, moving to shallow waters, hiding behind boats, or escaping by fleeing (Jefferson et al. 1991). In an evolutionary context, the annual migration undertaken by most baleen whale species from highlatitude summering grounds to low-latitude wintering grounds, where killer whales are less abundant, could also be a strategy to reduce predation risk (Corkeron \& Connor 1999).

The ecological role of killer whales as predators of baleen whales has been debated for a long time, as

() The authors 2018. Open Access under Creative Commons by Attribution Licence. Use, distribution and reproduction are unrestricted. Authors and original publication must be credited. 
predatory attacks have rarely been observed (Whitehead \& Glass 1985, Baird 2000, Clapham 2001, Connor \& Corkeron 2001, Springer et al. 2003, Reeves et al. 2006). It seems that even those killer whales specialized in eating marine mammals do not regularly prey on baleen whales, as observed, for example, for transient killer whales from the northeast Pacific that prey mainly on pinnipeds and small cetaceans and only occasionally on baleen whales (Ford et al. 2005, Matkin et al. 2007). Another explanation for the scarcity of records of killer whale attacks on baleen whales could be a shift of killer whale prey preferences due to the depletion of larger whale stocks caused by commercial whaling (e.g. Springer et al. 2003, DeMaster et al. 2006, Mizroch \& Rice 2006, Trites et al. 2007, but also see Wade et al. 2007). However, recent records of attacks on humpback whales Megaptera novaeangliae observed off Western Australia (see Pitman et al. 2015) have contributed new insights about the importance of predation pressure by killer whales on baleen whales at breeding grounds. In either a direct or opportunistic way, the predictability of their migration makes baleen whales more susceptible to predation by killer whales (Pitman et al. 2015).

Rake marks have been used as indirect evidence of predation attempts by killer whales on baleen whales, particularly humpback whales (e.g. Mehta et al. 2007, Steiger et al. 2008). Scars can be observed on the flukes in this species when the whales raise the tail before a long dive. Although other less exposed parts of the body might also be scarred, they are less visible and thus more difficult to evaluate. Rake marks on humpback whale flukes and on other baleen whales caused by killer whale attacks have been confirmed in different parts of the world (Mehta et al. 2007, Steiger et al. 2008, Reinhart et al. 2013) and are considered to be evidence of unsuccessful or non-lethal attacks (Dolphin 1987, Clapham 2001, Naessig \& Lanyon 2004, Mehta et al. 2007, Steiger et al. 2008, McCordic et al. 2014). It is not possible to establish the impact of killer whale predation on humpback whale populations based on such scars because scarred whales are survivors of unsuccessful attacks. However, the presence of killer whale rake marks on humpback whale flukes has been reported to be as high as $40 \%$ in some populations (Mehta et al. 2007, Steiger et al. 2008), indicating that important interactions occur between killer and humpback whales.

Humpback whale calves and yearlings seem to be more susceptible to killer whale attacks than larger, older cohorts (Reeves et al. 2006, Pitman et al. 2015). The likelihood of attack also seems to be higher dur- ing a whale's first migration from low-latitude breeding grounds to high-latitude feeding areas, suggesting that the marks are a once in a lifetime event resulting from an encounter with a killer whale (Clapham 1996, 2001, Mehta et al. 2007). However, this hypothesis is based on re-sightings of adult whales and not on multi-year sightings of individuals at different life history stages since they were calves (e.g. Mehta et al. 2007, Steiger et al. 2008).

Most accounts of interactions between killer and humpback whales are from the North Atlantic or North Pacific (e.g. Mehta et al. 2007, Steiger et al. 2008, Dahlheim \& White 2010, Ferguson et al. 2010, McCordic et al. 2014). Data for the southern hemisphere populations are scarce (e.g. Naessig \& Lanyon 2004, Pitman et al. 2015), particularly for the eastern South Pacific (ESP) (Flórez-González et al. 1994, Scheidat et al. 2000, Félix \& Haase 2001, Mehta et al. 2007, Capella et al. 2014).

In this study, we examined the incidence of rake marks on flukes of humpback whales belonging to Breeding Stock G, as referred to by the International Whaling Commission (2006). This population was estimated to comprise 6504 (95\% CI: 4270-9907) animals in 2006 (Félix et al. 2011). We considered the presence of rake marks to be indicative of non-lethal attacks and used the data to evaluate potential predation on humpback whales by killer whales. Our data come from several locations at feeding and breeding grounds along the ESP and the Antarctic Peninsula. Our goals were to determine how often, at what age, where, and when humpback whales were more susceptible to killer whale attacks.

\section{MATERIALS AND METHODS}

\section{Study area}

Breeding Stock $\mathrm{G}$ has the largest distribution of all humpback whale stocks in the world (Fig. 1). The breeding area extends from northern Peru $\left(6^{\circ} \mathrm{S}\right)$ to southern Costa Rica $\left(12^{\circ} \mathrm{N}\right)$ (Acevedo et al. 2007, Rasmussen et al. 2007, Pacheco et al. 2009), and the feeding area extends from the Antarctic Peninsula to subAntarctic waters of the Chilean fjords (Gibbons et al. 2003, Stevick et al. 2004). We included fluke data from animals photographed in 5 breeding and 2 feeding locations, collected by research groups led by the authors using different platforms, including researchdedicated surveys and opportunistic whale-watching vessels (see details in Flórez-González 1991, Félix \& Haase 2001, Capella et al. 2012, Guzman et al. 2015). 

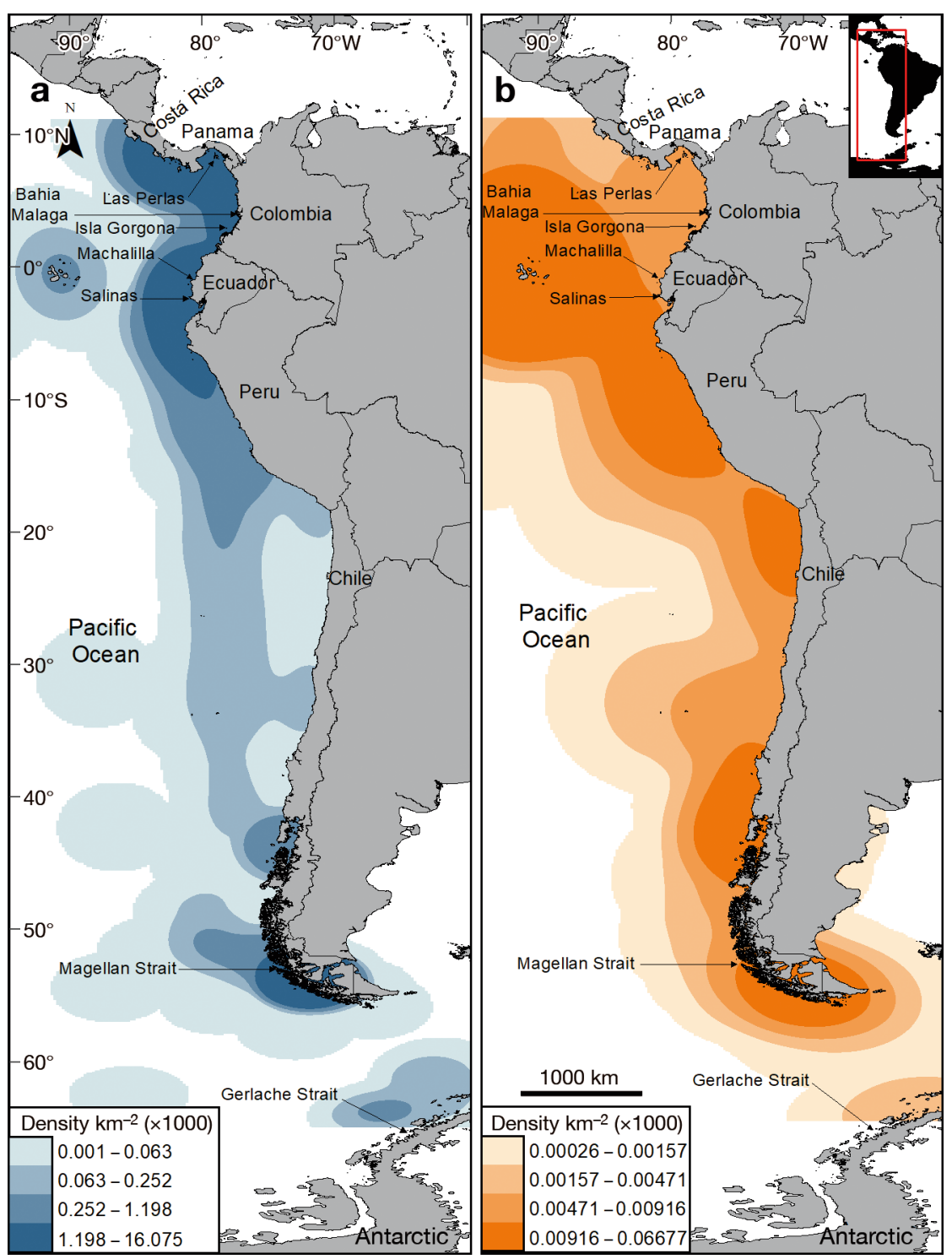

Fig. 1. Eastern South Pacific, showing the location of breeding and feeding areas (black arrows with site names) evaluated in this study as well as the density kernel distribution of satellite tracks from Guzman \& Félix (2017). Reported sightings data of (a) humpback whales and (b) killer whales in the region from SIBIMAP (www.sibimap.net)

\section{Assessment of rake marks}

Individual whales used in this study were selected from institutional ID catalogs compiled in the period 1986-2015 (Table 1), based on the best-quality photographs with appropriate focus, definition, and perspective of the ventral surface of the flukes (Katona \& Whitehead 1981). Rake marks were defined as a set of 3 or more parallel and equidistant linear scars on the ventral surface of the flukes (sensu Mehta et al. 2007). Analyzed images included only individuals for which images of both lobes of the tail were available to reduce bias by overestimating rates. Thereby, estimated rates should be considered as minimum values. Rake marks were solely attributed to encounters with killer whales and not to any other source (e.g. false killer whales Pseudorca crassidens) based on the length, width, and separation distance between the line scars (Mehta et al. 2007) as well as due to the lack of evidence of the presence of other potential predators of humpback whales in the region. Although scars on flukes could also have been produced when humpback whales interfered with attacks of killer whales (Pitman et al. 2017), we have insufficient data to evaluate this issue.
Data from the Antarctic Peninsula were obtained from research vessels. Monitored sites at breeding grounds included Las Perlas Archipelago $\left(8^{\circ} 22.414^{\prime} \mathrm{N}, 79^{\circ}\right.$ $\left.1.987^{\prime} \mathrm{W}\right)$ in Panama; Gorgona Island $\left(2^{\circ} 58.244^{\prime} \mathrm{N}, 78^{\circ}\right.$ 11.028' W) and Málaga Bay ( $\left.3^{\circ} 56.274^{\prime} \mathrm{N}, 77^{\circ} 19.905^{\prime} \mathrm{W}\right)$ in Colombia; and Salinas ( $\left.2^{\circ} 11.67^{\prime} \mathrm{S}, 80^{\circ} 58.3^{\prime} \mathrm{W}\right)$ and Machalilla (1 ${ }^{\circ} 32.06^{\prime} \mathrm{S}, 80^{\circ} 49.9^{\prime} \mathrm{W}$ ) in Ecuador. Feeding locations included the Magellan Strait $\left(53^{\circ}\right.$ $\left.40.754^{\prime} \mathrm{S}, 72^{\circ} 14.354^{\prime} \mathrm{W}\right)$ off southern Chile and the Gerlache Strait $\left(64^{\circ} 30^{\prime} \mathrm{S}, 62^{\circ} 20^{\prime} \mathrm{W}\right)$ in the western Antarctic Peninsula.

\section{Age/class categories}

During fieldwork, individuals were assigned to 1 of 3 age classes based on the relative size of the animals: (1) adult: length $>12 \mathrm{~m}$ (visual estimation) or older than $4.5 \mathrm{yr}$ (when age was known); (2) calf: individuals $<9$ mo old and $8 \mathrm{~m}$ in length that maintained a constant/close relationship with an adult (presumably the mother); or (3) juvenile: whales of known age (1.5-4.5 yr). The latter category was established with certainty only for the Magellan 
Table 1. Percentage of rake marks in the flukes of 2909 adult and 133 calf humpback whales from the eastern South Pacific and the Antarctic Peninsula. Individuals were selected based on photo quality. Source: source of the catalog from which photos were taken. 'Total analyzed' includes all individuals initially screened from catalogs, including individuals that were removed because only 1 lobe was visible or because of limited definition of the fluke image. (-) No values available

\begin{tabular}{|c|c|c|c|c|c|c|c|c|c|c|}
\hline \multirow[t]{2}{*}{ Location } & \multirow{2}{*}{$\begin{array}{l}\text { Sampling } \\
\text { period }\end{array}$} & \multirow[t]{2}{*}{ Source } & \multicolumn{2}{|c|}{ Total analyzed } & \multicolumn{2}{|c|}{ Total selected } & \multicolumn{2}{|c|}{ Rakes in adults } & \multicolumn{2}{|c|}{ Rakes in calves } \\
\hline & & & Adult & Calf & Adult & Calf & $\mathrm{N}$ & Rate & $\mathrm{N}$ & Rate \\
\hline Las Perlas (Panama) & 2003-09 & Smithsonian Institution & 133 & 9 & 128 & 8 & 18 & 0.140 & 1 & 0.125 \\
\hline Malaga Bay (Colombia) & 1993-01 & Fundación Yubarta & 170 & 63 & 147 & 46 & 13 & 0.088 & 3 & 0.065 \\
\hline Gorgona Is. (Colombia) & 1986-04 & Fundación Yubarta & 762 & 20 & 581 & 8 & 66 & 0.113 & 1 & 0.125 \\
\hline Salinas-Machalilla (Ecuador) & 1991-13 & Museo Ballenas & 2151 & 15 & 1827 & 15 & 205 & 0.112 & 2 & 0.133 \\
\hline Magellan Strait (Chile) & $1999-15$ & Whalesound & 158 & 63 & 157 & 56 & 25 & 0.159 & 19 & 0.339 \\
\hline Gerlache Strait (Antarctic) & $2012-15$ & Museo Ballenas & 69 & 0 & 69 & 0 & 8 & 0.116 & - & - \\
\hline Total & $1986-15$ & & 3443 & 170 & 2909 & 133 & 335 & 0.115 & 26 & 0.195 \\
\hline
\end{tabular}

Strait due to availability of long-term individual data. In the case of data from breeding grounds, as not all research groups distinguished the category 'juveniles' in the field, all non-calf individuals were considered adults for the purpose of this study.

\section{Intensity of rake marks}

Rake marks were categorized according to the intensity of the injury as follows: (1) no rake marks on flukes (unmarked); (2) low: a single set of rake marks on 1 lobe or 2 sets of marks affecting $<10 \%$ of the lobe; (3) medium: at least 1 set of rake marks per lobe or $>2$ rake marks on 1 side covering up to $50 \%$ of the lobe; and (4) high: numerous marks covering more than half of the fluke and/or with missing sections on fluke tips or border (Fig. 2).

\section{Prevalence of rake marks}

Photographs of flukes of 3613 individuals (3443 adults and 170 calves) were examined, but only 2909 adults and 133 calves (a total of 3042) were selected and used for further analyses based on the defined quality criteria. All selected individuals identified from each site were included in the analyses based on the best photograph available for each individual. If an individual moved between sites, it was assigned to the location at which it was first sighted.

\section{Acquisition rate of rake marks}

The acquisition rate of rake marks as a function of sex and age was estimated by analyzing multi-year individual sighting data, which were only available for the Magellan Strait. The dataset contained 157 individuals, of which 94 (59.8\%) were sexed using molecular techniques (Sabaj et al. 2004) or considered female when an adult was closely and consis-

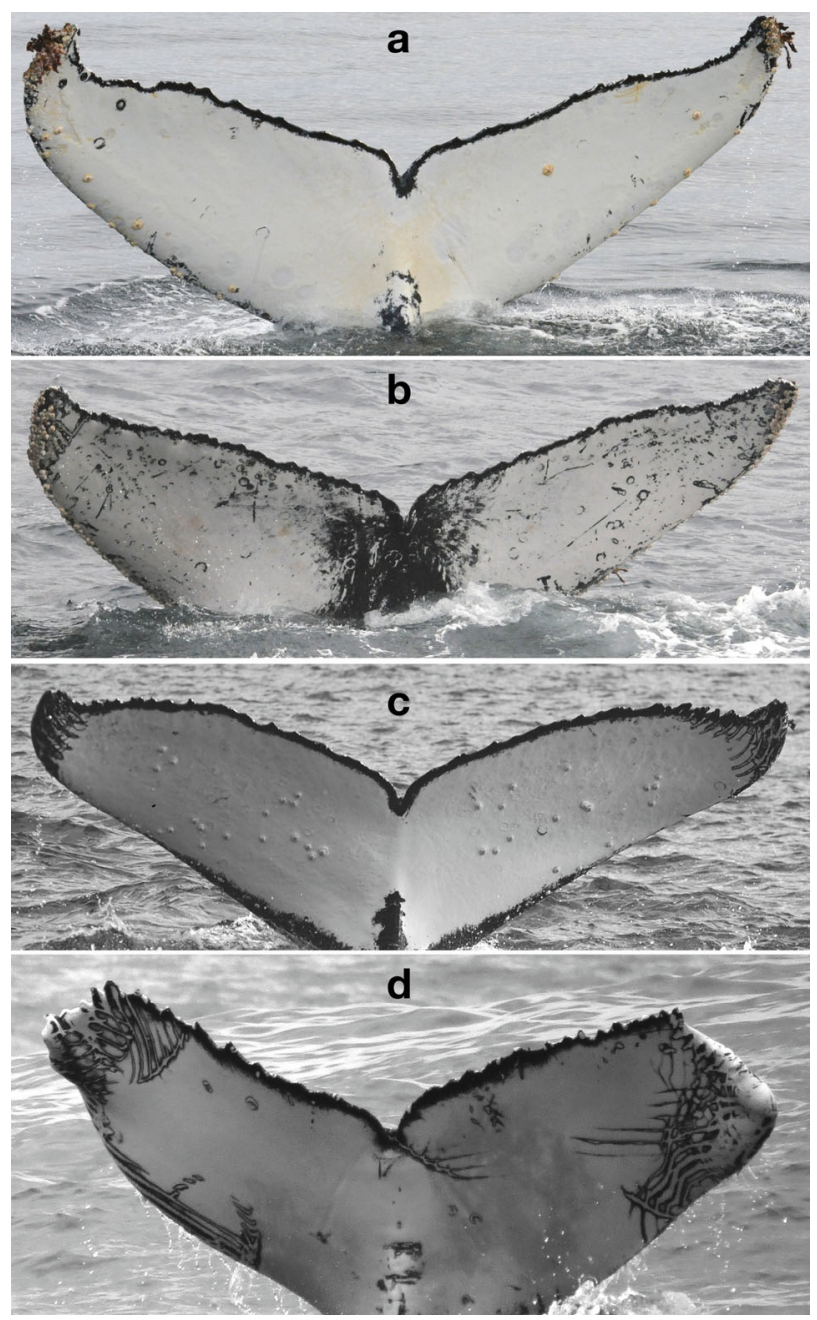

Fig. 2. Humpback whale flukes with rake marks of different intensity: (a) unmarked, (b) low, (c) medium, (d) high intensity 
tently accompanied by a calf. Overall, 120 individuals were sighted for the first time as adults and 37 as calves during the period 1999-2015. A subset of 28 adult females, which calved from 1 to 5 offspring during this period, were used to determine whether the presence of a new calf influenced the acquisition of new fluke rake marks and to identify any possible bias related to breeding conditions. At this site, individuals exhibited up to $80 \%$ interannual return $(\mathrm{SD}=$ $10 \%$, range $66.7-92.5 \%$ ), with 75 whales returning annually for 5 or more years (Capella et al. 2012, Acevedo et al. 2014). This analysis was not possible for breeding sites due to the low interannual re-sighting rate, which was usually lower than $20 \%$ (FlórezGonzález 1991, Capella et al. 2008, Félix et al. 2011, Guzman et al. 2015).

\section{Data modeling}

A series of additive and interactive generalized linear models (McCullagh \& Nelder 1989) were used to test whether the presence or absence of rakes (response variable) in humpback whales ( $\mathrm{n}=$ 3042) was a factor of the following 3 explanatory variables: ground (breeding, feeding), age (calf, adult-juvenile), and year (1986-2015). Five models were fitted and compared using Akaike's information criterion (AIC): 1 with a 3-way interaction (rake $\sim$ year $\times$ age $\times$ ground, family $=$ binomial); 2 with a 2 way interaction (rake $\sim$ year $\times$ age, family $=$ binomial; and rake $\sim$ year $\times$ ground, family $=$ binomial); 1 with ground as an additive term (rake $\sim$ year + ground, family = binomial); and 1 with age as an interactive term and ground as an additive (rake $\sim$ year $\times$ age + ground, family = binomial). The models were fit with the function ' $\mathrm{glm}$ ' in the $\mathrm{R}$ software environment version 3.2.2 (R Core Team 2015) with binomial family and logit link. Model significance was tested with analysis of variance and chi-squared tests, and predicted odds were estimated with the 'predict' function.

\section{Sighting data and species distribution}

Georeferenced sighting data on humpback and killer whales off the west coast of South America from the Regional System on Marine Biodiversity and Protected Areas of the Southeast Pacific (SIBIMAP), compiled by the Permanent Commission for the South Pacific (www.sibimap.net), were used for an additional analysis on the spatial distribution of both species. Data from SIBIMAP include both published and unpublished information from oceanographic cruises, seismic prospection surveys, and the Cetacean Sighting Network of the Chilean Navy. The dataset included 194 killer whale and 2214 humpback whale sighting records, containing a total of 949 and 5018 individuals, respectively. In addition, data from satellite transmissions on humpback whales were also included in this analysis (see Guzman \& Félix 2017). Distribution ranges were calculated for both species using the kernel density estimator to generate surface values indicating higher or lower utilization of the space with the Spatial Analyst tool in ArcGis, Version 10.2.2.

\section{RESULTS}

\section{Rake mark prevalence}

Rake marks were found in 361 of the 3042 individuals assessed $(11.86 \%)$ (Table 1). The sample size was highly variable between locations and between feeding and breeding areas. The largest photograph datasets were from Ecuador (60.5\%) and Colombia (25.7\%). The photograph dataset from the feeding grounds represented $9.2 \%$ of the total sample.

Overall rake prevalence rates of 0.115 for adult whales (335 of 2909) and 0.195 for calves (26 of 133) were found (Table 1). The prevalence of rake marks on flukes ranged from 0.088 to 0.159 in adults and from 0.065 to 0.339 in calves (Table 1 ). The proportion of rake marks in adults from breeding (mean = $0.11, \mathrm{SD}=0.02)$ and feeding areas (mean $=0.14, \mathrm{SD}=$ $0.03)$ was not significantly different $\left(\chi^{2}=2.02, \mathrm{p}>\right.$ $0.05)$, but the proportion of rake marks in calves between breeding and feeding areas (mean $=0.11$ vs. 0.34 , respectively) was highly significant $\left(\chi^{2}=10.23\right.$, $\mathrm{p}<0.01)$, representing a $3.1 \times$ increase. No data on calves from the Antarctic were available for this comparison.

The intensity of rake marks on flukes was assessed in adult whales for each site except Gerlache Strait in the Antarctic Peninsula (because of its small sample size, $\mathrm{n}=8$ ). The most frequent category was unmarked, with an average of $87.7 \%(\mathrm{SD}=2.8 \%$, range 84.1-91.2\%, n = 2513; Fig. 3). Among marked whales, the most frequent category was low intensity, with an average of $57.4 \%$ (SD $=5.8 \%, \mathrm{n}=171)$ of all scarred whales (ranging from $47.8 \%$ in Salinas-Machalilla to $61.5 \%$ in Malaga Bay). The medium intensity category averaged $27.8 \%(\mathrm{SD}=6.8 \%, \mathrm{n}=79)$ of scarred 


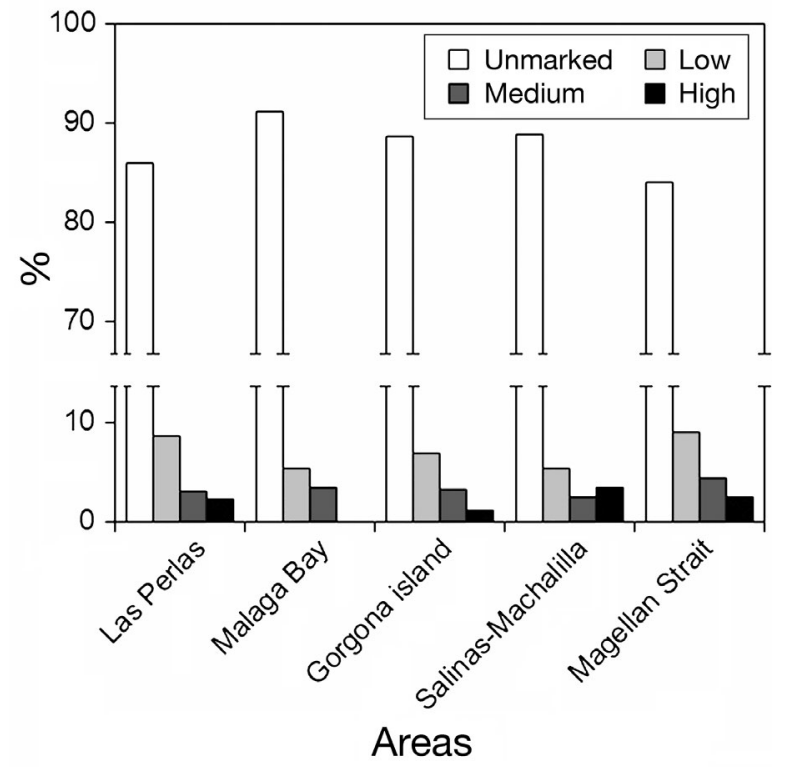

Fig. 3. Percentage of rake marks of 4 different intensities (as defined in the 'Materials and methods'; see also Fig. 2) on flukes of adult and juvenile humpback whales inhabiting the eastern South Pacific $(n=327)$

whales (ranging from $21.5 \%$ in Salinas-Machalilla to $38.5 \%$ in Malaga Bay). The high intensity category averaged $14.8 \%(\mathrm{SD}=11.1 \%, \mathrm{n}=77)$ of scarred whales (ranging from $0 \%$ in Malaga Bay to $30.7 \%$ in Salinas-Machalilla). This last category was the most variable among the 3 categories and was significantly higher in Salinas-Machalilla and significantly lower in Malaga Bay $\left(\chi_{8}^{2}=28.43, \mathrm{p}<0.01\right)$.

\section{Acquisition of rake marks}

No acquisition of rakes in unmarked individuals or new rakes in individuals first identified with rake marks as adults were found in breeding areas throughout the study period $(\mathrm{n}=391)$. Multi-year sightings data from the Magellan Strait dataset also revealed no new marks in subsequent observations of animals first observed with scars $(n=32 ; 22$ adults and 10 calves) or first observed unmarked $(\mathrm{n}=108$; 81 adults and 27 calves). None of the 27 unmarked calves with return histories to Magellan Strait (average 5 different years, $\mathrm{SD}=3$, range 2-11) acquired new rake marks either as juveniles or adults (maximum 11.5 yr old) (Table 2).

Of 25 whales with rake marks in the Magellan Strait, 7 were males $(28 \%), 8$ were females $(32 \%)$, and 10 were of undetermined sex $(40 \%)$. Of the 132 whales without rake marks, 39 were males
$(29.5 \%), 44$ were females $(33.3 \%)$, and 49 were of undetermined sex $(37.1 \%)$. No sex bias was found regarding rake marks, as the proportion between sexes was not significantly different $\left(\chi^{2}=0.144\right.$, $p>0.05)$. We also assessed the acquisition of new rake marks in either unmarked or marked adult females that calved during the study period in the Magellan Strait (1999-2015). Mothers with initial fluke rake marks $(\mathrm{n}=5)$ produced 16 calves: 5 $(31 \%)$ acquired rake marks, $6(38 \%)$ did not, and presence/absence could not be determined in the other 5 calves $(31 \%)$, as the calves did not expose their flukes. Initial unmarked mothers $(\mathrm{n}=29)$ produced 64 calves: 14 (22\%) acquired rake marks, 31 $(48 \%)$ did not, and presence/absence could not be determined in the other $19(30 \%)$. No significant differences were found in the proportion of marked, unmarked, and undetermined calves between marked and unmarked mothers $\left(\chi^{2}=0.84\right.$, $\mathrm{p}>0.05)$. In addition, mothers that experienced a killer whale attack prior to calving had a higher calving rate than unmarked mothers (3.2 and 2.2 calves female $^{-1}$, respectively).

\section{Long-term dynamics}

The model with the lowest AIC value showing the interaction (age $\times$ location) of the 4 competing models was used to examine the presence or absence of rake marks (Table 3). The result of the generalized linear model of the complete 3-way interaction between whale age, site, and year was not significant $\left(\chi^{2}=1.22 \mathrm{p}>0.05\right)$. However, when the model was reduced to the interaction between age and year (and ground as an additive term), a significant relationship was found $\left(\chi^{2}=5.04, p<0.05\right)$. Thus, there was a different relationship between the presence of rake marks and year than between calf and adult whales and ground (Fig. 4). The odds of having rake marks increased with time from 1986 to 2015, and this increase was remarkably higher in calves at both breeding and feeding grounds.

\section{Sighting distribution analysis}

Information available from the SIBIMAP dataset on humpback and killer whales shows that both species are found throughout the ESP region, including breeding, feeding, and migratory routes for humpback whales (Fig. 1). Distribution overlapping includes both coastal and offshore waters, but is partic- 
Table 2. Multi-year sighting history of 37 calves (identified by their flukes) that returned to the Magellan Strait feeding area. Empty spaces indicate no available data. A: flukes without rake marks; P: flukes with rake marks; NP: flukes without new rake marks; M: Male; F: Female; UN: sex undetermined

\begin{tabular}{|c|c|c|c|c|c|c|c|c|c|c|c|c|c|}
\hline \multirow[t]{2}{*}{ Sex } & \multirow[t]{2}{*}{ ID } & & & & & & \multicolumn{2}{|c|}{ Age (yr) } & \multirow[b]{2}{*}{7.5} & \multirow[b]{2}{*}{8.5} & \multirow[b]{2}{*}{9.5} & \multirow{2}{*}{\multicolumn{2}{|c|}{10.511 .5}} \\
\hline & & $<1$ & 1.5 & 2.5 & 3.5 & 4.5 & 5.5 & 6.5 & & & & & \\
\hline M & 59 & A & & A & A & & & & & A & & & A \\
\hline $\bar{F}$ & 65 & $\mathrm{~A}$ & A & $\mathrm{A}$ & & A & A & A & A & $\mathrm{A}$ & A & A & A \\
\hline $\mathrm{F}$ & 78 & A & $\mathrm{A}$ & $\mathrm{A}$ & A & $\mathrm{A}$ & A & $\mathrm{A}$ & $\mathrm{A}$ & $\mathrm{A}$ & $\mathrm{A}$ & A & \\
\hline $\mathrm{F}$ & 79 & A & A & & & & & & & & & & \\
\hline $\mathrm{F}$ & 80 & $\mathrm{P}$ & & NP & NP & NP & NP & NP & NP & NP & NP & & \\
\hline $\bar{F}$ & 91 & $\mathrm{~A}$ & A & $\mathrm{A}$ & $\mathrm{A}$ & $\mathrm{A}$ & $\mathrm{A}$ & $\mathrm{A}$ & $\mathrm{A}$ & $\mathrm{A}$ & $\mathrm{A}$ & A & \\
\hline$\overline{\mathrm{M}}$ & 97 & $\mathrm{~A}$ & $\mathrm{~A}$ & $\mathrm{~A}$ & $\mathrm{~A}$ & $\mathrm{~A}$ & A & A & A & A & $\mathrm{A}$ & & \\
\hline $\mathrm{F}$ & 99 & $\mathrm{P}$ & & & NP & NP & & & & & & & \\
\hline $\mathrm{F}$ & 101 & $\mathrm{P}$ & NP & & NP & & & NP & & & & & \\
\hline $\mathrm{UN}$ & 103 & $\mathrm{P}$ & & NP & & & & & & & & & \\
\hline $\mathrm{F}$ & 105 & $\mathrm{~A}$ & & A & $\mathrm{A}$ & A & A & A & A & A & A & & \\
\hline $\mathrm{F}$ & 109 & A & & & A & A & A & & A & A & A & A & \\
\hline F & 115 & $\mathrm{~A}$ & A & A & A & A & $\mathrm{A}$ & A & $\mathrm{A}$ & & & & \\
\hline UN & 117 & A & & & A & $\mathrm{A}$ & A & & & & & & \\
\hline UN & 118 & A & A & & A & & & & & & & & \\
\hline UN & 119 & $\mathrm{P}$ & & & NP & NP & NP & NP & NP & NP & NP & & \\
\hline UN & 120 & A & & A & & A & A & A & $\mathrm{A}$ & & & & \\
\hline$\overline{\mathrm{UN}}$ & 121 & $\mathrm{~A}$ & & $\mathrm{~A}$ & & & & & & & & & \\
\hline $\mathrm{UN}$ & 122 & $\mathrm{~A}$ & A & $\mathrm{A}$ & A & A & A & A & A & & & & \\
\hline UN & 127 & A & A & & & A & A & & & & & & \\
\hline UN & 128 & A & & & & A & A & & & & & & \\
\hline$\overline{\mathrm{UN}}$ & 129 & $\mathrm{P}$ & & & NP & & & NP & & & & & \\
\hline$\overline{\mathrm{UN}}$ & 130 & $\mathrm{~A}$ & A & A & $\mathrm{A}$ & & & & & & & & \\
\hline UN & 134 & $\mathrm{~A}$ & & A & & & & & & & & & \\
\hline$\overline{\mathrm{M}}$ & 141 & A & & & & & A & & & & & & \\
\hline UN & 142 & A & & & A & A & A & A & & & & & \\
\hline UN & 143 & A & & & & & A & & & A & & & \\
\hline$\overline{\mathrm{UN}}$ & 144 & A & & & & & & A & & & & & \\
\hline UN & 145 & A & & A & A & A & A & & & & & & \\
\hline$\overline{\mathrm{UN}}$ & 146 & A & & & & & & A & A & & & & \\
\hline UN & 152 & A & & A & A & $\mathrm{A}$ & & & & & & & \\
\hline UN & 153 & $\mathrm{P}$ & & & NP & NP & & & & & & & \\
\hline UN & 156 & $\mathrm{P}$ & & & NP & NP & & & & & & & \\
\hline$\overline{\mathrm{UN}}$ & 157 & A & & & & $\mathrm{A}$ & & & & & & & \\
\hline$\overline{\mathrm{UN}}$ & 158 & A & & & A & & & & & & & & \\
\hline UN & 163 & $\mathrm{P}$ & & & NP & & & & & & & & \\
\hline$\overline{\mathrm{UN}}$ & 165 & $\mathrm{P}$ & & NP & & & & & & & & & \\
\hline
\end{tabular}

Table 3. Results of Akaike's information criterion (AIC) analysis for the 4 competing models used to examine the presence or absence (response variable) of rake marks on humpback whale flukes. Significance is indicated by asterisks $\left({ }^{* *} \mathrm{p}<0.01,{ }^{* * *} \mathrm{p}<0.001\right)$

\begin{tabular}{|lcc|}
\hline Explanatory variable & $\mathrm{p}$ & $\mathrm{AIC}$ \\
\hline Location (breeding or feeding ground) & $0.0007^{* * *}$ & 2208.8 \\
Age (calf or adult/juvenile) & $0.00919^{* *}$ & 2213.4 \\
Age + Location & Age: 0.072390 & 2207.6 \\
Age $\times$ Location & Location: $0.005118^{* *}$ & \\
& Interaction: $0.007800^{* *}$ & 2202.5 \\
\hline
\end{tabular}

ularly more pronounced at breeding grounds around the Galapagos Archipelago, southern Ecuador, off Peru, as well as along most of the coast of Chile. The humpback whale dataset for breeding grounds is likely biased towards the coast because research effort was concentrated in coastal areas. On the other hand, most data from killer whales are from oceanographic cruises and are therefore less biased.

\section{DISCUSSION}

This is the first study on non-lethal predatory encounters between humpback and killer whales inhabiting the ESP and the Antarctic Peninsula using rake marks as indirect evidence of predation. We confirm that in the southeast Pacific humpback whale population, predation by killer whales mainly occurs at breeding grounds or during the first migration to feeding grounds, in similar ways as proposed for other populations (Clapham 1996, 2001, Mehta et al. 2007). This belief is supported by differences in the proportion of rake marks in calves between breeding and feeding sites in the ESP (9\% at breeding grounds and $34 \%$ at the Magellan Strait feeding site) and the lack of acquisition of new marks after the first year of life. Additionally, despite numerous sightings of killer whales $(n=63)$ during the summers of 2004 to 2012 in the Magellan Strait, no attacks on humpback whales were observed, while feeding on sea lions, fish, and sea birds was recorded (Capella et al. 2014). Killer whale chasing behavior on sei whales Balaenoptera borealis (but not on humpbacks) was observed $1000 \mathrm{~km}$ north of the Magellan Strait in the North Patagonian fjords, a secondary humpback feeding ground (HuckeGaete et al. 2013) and also in the Beagle channel, $200 \mathrm{~km}$ south of the Magellan Strait (R. N. P. Goodall pers. comm.). The diet of killer whales in northern fjords is also composed mainly of sea lions, fur seals, and sea birds (Häussermann et al. 2013). 


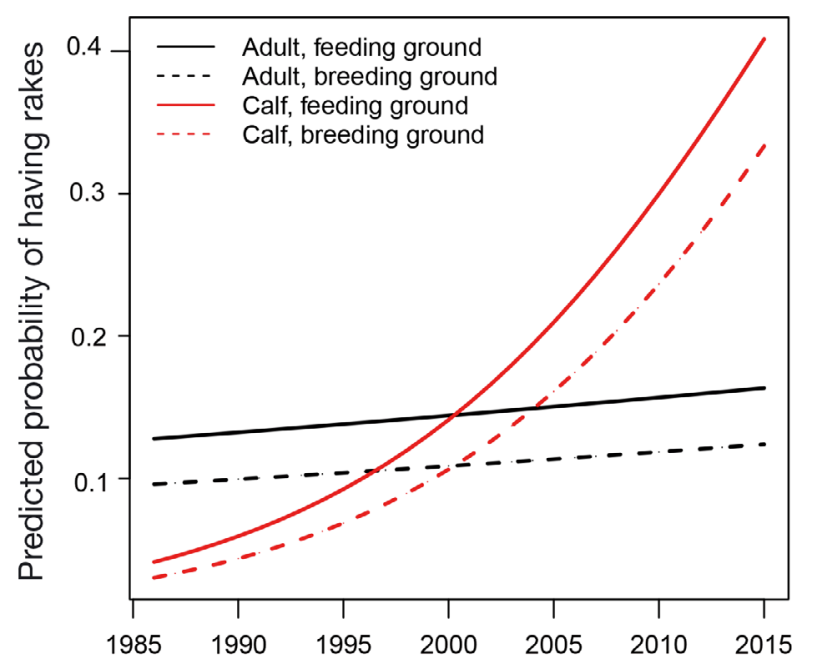

Fig. 4. Probability of having rake marks over time (years) for calves and adult humpback whales at both breeding (Panama, Colombia, and Ecuador) and feeding grounds (eastern South Pacific and Antarctic Peninsula). Data span the period 1986-2015

We consider our sample size to be representative of Breeding Stock G at 2 feeding locations (Magellan and Gerlache Straits) and 5 breeding locations along the coasts of 3 countries (Panama, Colombia, and Ecuador) (Stevick et al. 2004, Acevedo et al. 2007, Guzman et al. 2015). The conclusions of this study benefit from the analysis of large datasets (2909 adult and 133 calves selected) that encompass a large proportion of individuals belonging to Breeding Stock G (see Félix et al. 2011).

Overall, the prevalence of rake marks on adult humpback whales in both feeding and breeding areas $(11.5 \%$, range $8.8-15.9 \%)$ was in the range of that reported for other populations elsewhere (globally $1.2-40.1 \%$, Mehta et al. $2007 ; 5-31 \%$ for the North Pacific, Steiger et al. 2008; $2.7-17.4 \%$ for the North Atlantic, McCordic et al. 2014; $15.9-31.3 \%$ off western and eastern Australia, Tonga, and New Caledonia, Mehta et al. 2007, Naessig \& Lanyon 2004). Our results are also consistent with those of Steiger et al. (2008) regarding the lack of differences in the proportion of scarring in adults between breeding and feeding areas. However, the data from the Antarctic Peninsula contrast with those for the same area reported by Mehta et al. (2007), who estimated a rake mark prevalence of $1.2 \%$ based on 164 individuals assumed to be adults. This value seems to be an underestimation compared with our findings from the Gerlache Strait, Antarctic Peninsula $(11.6 \%)$, and from the Magellan Strait (15.9\%), a secondary feeding location in southern Chile.
We found that both males and females were scarred to comparable extents in the Magellan Strait, where almost equal overall sex ratios exist (Capella et al. 2012, Acevedo et al. 2014), which is expected at feeding grounds (Clapham et al. 1995). The absence of additional scars in adults sighted in multiple years and in multi-calving females, even those with already scarred calves, could be explained by killer whales avoiding the tails of adults and mothers during attacks, either by attacking other body parts, as reported by Flórez-González et al. (1994) and Pitman et al. (2015), or by just focusing on the calf.

Anti-predator behaviors by humpback whales include the presence of escorts to defend the mothercalf pair (Clapham 1996, Pitman et al. 2015) as well as interfere with attacks by killer whales on other aquatic mammals (Pitman et al. 2017), and also approaching shallow areas where killer whales would have less maneuverability (Jefferson et al. 1991, Pitman et al. 2015). A preference for nearshore waters, especially by mother-calf pairs (Ersts \& Rosenbaum 2003, Félix \& Botero-Acosta 2011, Craig et al. 2014), has been mentioned as a strategy for protection from killer whale predation (Pitman et al. 2015), which would extend during the migration. Female humpback whales and their calves take a more coastal migratory route than other adults towards feeding grounds, as has been shown with satellite tracking data in the ESP (Félix \& Guzman 2014), and has also been observed along eastern Australia (Franklin et al. 2018). Additionally, our data from the Magellan Strait indicate that females that were attacked as calves (scarred whales that survived the attack) arrived at feeding areas with a higher number of calves that survived the first migration (3.2 female $^{-1}$ ) than non-attacked (non-scarred) females (2.2). However, no data are available about calf mortality during the breeding season and migration. This apparent higher survival of calves at the first migration suggests that females attacked when young may develop anti-predator tactics to avoid killer whale predation on their own calves as a result of their individual experiences.

The spatiotemporal patterns of attacks by killer whales seem to be dependent on species and geographic location. Our results for ESP humpback whales are therefore not necessarily comparable with information for other baleen whales. For example, the incidence of attacks on bowhead whales Balaena mysticetus is higher for old adults than for sub-adults and juveniles, as rake marks are cumulative over time for each individual (Reinhart et al. 2013). 
On the other hand, the hypothesis of predation risk reduction as a major selective advantage for baleen whales to explain their annual migration towards lower latitudes to breed (Corkeron \& Connor 1999, Connor \& Corkeron 2001) is not supported by our study (see also Steiger et al. 2008), at least for humpback whales. The fact that other baleen species such as bowheads and pygmy right whales Caperea marginata do not migrate for breeding in the tropics also suggests that several factors are associated with whale migration. The results of our study regarding the timing of scar acquisition, based on data on rake marks in calves and adults/juveniles, and multi-year sighting history (including the transition from calf to adult) from the Magellan Strait, strongly support the hypothesis that killer whale attacks occur specifically on calves (Clapham 1996, 2001). Available data on the distribution of both humpback whales and killer whales along the ESP shows a clear overlap and supports the hypothesis that predation occurs either at the breeding site or during the migration. Similar predation patterns by transient killer whales on calves of gray whales Eschrichtius robustus during the migration to feeding grounds have also been reported along the northeast Pacific (Barrett-Lennard et al. 2011, Pittman et al. 2015).

Modeling results show a significantly higher increase in odds of having rake marks in calves during the study period (1986-2015) at both breeding and feeding grounds compared to adults. This may be because killer whale populations preying on baleen whales increased as baleen whale populations rebounded after the whaling moratorium or because there was a shift (return) in killer whale predation on baleen whales because of increased availability of baleen whales. Killer whale sightings seem to have increased in tropical areas from Costa Rica to Peru. For example, there were 50 sightings near Machalilla, Ecuador, between 1997 and 2004, with 8 cases in which humpbacks were charged and attacked (Castro et al. 2005), and 5 sightings between 2013 and 2016, resulting in 3 calves killed (C. Castro pers. comm.). At least 33 sightings were reported during several pelagic surveys in Peru (Garcia-Godos 2004, summarized by Guerrero-Ruiz et al. 2005), and 5 sightings were made between 2011 and 2017 in Panama (H. M. Guzman unpublished data). Consequently, an increase in attacks can be expected (sensu Pitman et al. 2017). Although in some cases, increased killer whale sightings may be the result of increased effort, in others such as in Ecuador the effort has been more uniform, and therefore the trend seems real.
Almost 3/4 of flukes with rake marks in ESP humpback whales (11.86\% of the total dataset) had low to moderate scarring. Previous studies have reported that two-thirds or more of the humpback whales studied had rake marks at the mid-to-moderate scarring level, and $<10 \%$ had severe scarring (Naessig \& Lanyon 2004, Mehta et al. 2007, Steiger et al. 2008). We interpret these results as follows: (1) attacks resulting in severe damage (as defined here) are rare, and (2) attacks resulting in severe damage are often lethal. The significantly higher proportion of whales with severe scarring observed in Salinas-Machalilla (Ecuador) with respect to other breeding locations may be related to different predation pressure at the sampled locations and the fact that this population shows a high level of stratification at breeding grounds (Guzman \& Félix 2017). Further research on killer whale distribution and movements is required in this part of the ESP.

\section{CONCLUSIONS}

We set out to determine how often, at what age, where, and when humpback whales were most susceptible to attack and/or acquisition of rake scars from killer whales in the ESP. We conclude the following:

(1) The frequency of rake marks on flukes of adult humpbacks in feeding and breeding sites in the ESP and the Antarctic was comparable to values reported elsewhere.

(2) The incidence of rake marks on calves was significantly higher at feeding than at breeding grounds. Therefore, calves acquired rake marks at breeding sites and during the first migration to feeding areas.

(3) Multi-year sightings of 103 adults and 37 calves from the Magellan Strait revealed no new marks on flukes after the initial sighting. No whales acquired rake marks either as juveniles or adults.

(4) Calf presence did not cause the acquisition of new rake marks in either unmarked or marked mothers. None of the mothers gained scars or new marks during calving. Calves from both types of mothers were comparably susceptible to acquiring rake marks.

(5) An attack with non-lethal consequence on a female calf seemed to have a positive impact a posteriori, increasing survival of her own offspring.

(6) Calves showed a significant increase in the probability of having rake marks during the study period compared to adults, which suggests an increase in predation pressure over time. 
Acknowledgements. We thank several contributors to institutional catalogs including Natalia Botero, Jéssica Falconí, Paulo Simoes, and Alfredo Carrasco. Three anonymous reviewers provided valuable comments to improve this document. Different phases of this long-term study have been supported by Whalesound Ltda., Universidad Santo Tomás (Grant INV-5-03-01), Universidad de Magallanes (Grant 021500), Agencia Española de Cooperación Internacional y Desarrollo (Grants D/010828/07 and D/010828/08), FONDECYT (Grant 029700), and Mineduc (PMI Gaia Antarctica) and Corporación de Fomento de la Producción (CORFOGrant 17PIRE-72232) from Chile, Museo Ballenas from Ecuador, Fundación Yubarta, Colciencias, and WWF from Colombia, the Smithsonian Tropical Research Institute and Secretaría Nacional de Ciencia, Tecnología e Innovación from Panama (SENACYT), the International Community Foundation-CANDEO, DEFRA's Darwin Initiative Fund (UK), and Heriot-Watt University. Biopsy samples from the Magellan Strait were collected under permit of Subsecretaria de Pesca y Acuicultura, Ministry of Economy of Chile. We also thank the Ministerio de Bienes Nacionales, Instituto de Fomento Pesquero (IFOP), Dirección del Territorio Marítimo, and Ministerio del Medio Ambiente in Chile, Ministerio del Medio Ambiente y Unidad Especial de Parques Nacionales in Colombia, and Autoridad de Recursos Marinos de Panama and Autoridad Nacional del Ambiente in Panama for support and for facilitating the permits to conduct the studies. Special thanks to Compañía Minera del Pacífico for providing field support to some authors and to Catalina Gomez and Ana Piñeiro for statistical advice and performing the model analyses.

\section{LITERATURE CITED}

Acevedo J, Rasmussen K, Félix F, Castro C and others (2007) Migratory destinations of humpback whales from the Magellan Strait feeding ground, Southeast Pacific. Mar Mamm Sci 23:453-463

* Acevedo J, Mora C, Aguayo-Lobo A (2014) Sex-related site fidelity of humpback whales (Megaptera novaeangliae) to the Fueguian Archipelago feeding area, Chile. Mar Mamm Sci 30:433-444

Baird RW (2000) The killer whale-foraging specializations and group hunting. In: Mann J, Connor R, Tyack P, Whitehead $\mathrm{H}$ (eds) Cetacean societies: field studies in behavior. University of Chicago Press, Chicago, IL, p 125-153

Barrett-Lennard LG, Matkin CO, Durban JW, Saulitis EL, Ellifrit D (2011) Predation on gray whales and prolonged feeding on submerged carcasses by transient killer whales at Unimak Island, Alaska. Mar Ecol Prog Ser 421: 229-241

Capella JJ, Gibbons J, Florez-Gonzalez L, Llano M, Valladares C, Sabaj V, Vilina YA (2008) Migratory round-trip of individually identified humpback whales at the Strait of Magellan: clues on transit times and phylopatry to destinations. Rev Chil Hist Nat 81:547-560

Capella J, Gibbons J, Vilina YA, Flórez-González L, Sabaj V, Valladares C (2012) Abundance, population structure and fidelity of humpback whale in the Strait of Magellan, Chile. Report to the Scientific Committee of the 64th Annual Meeting of the International Whaling Commission, Panama, SHWP2. IWC, Cambridge

Capella J, Abramson JZ, Vilina Y, Gibbons J (2014) Observations of killer whales (Orcinus orca) in the fjords of
Chilean Patagonia. Polar Biol 37:1533-1539

Castro C, Forestell P, Kaufman G, Scheidat M (2005) Current knowledge of orca (Orcinus orca) attacks on humpback whales (Megaptera novaeangliae) in the Machalilla National Park, Ecuador. 16th Biennial Conference on the Biology of Marine Mammals, San Diego, CA, USA, 12-16 December

Clapham PJ (1996) The social and reproductive biology of humpback whales: an ecological perspective. Mammal Rev 26:27-49

Clapham PJ (2001) Why do baleen whales migrate? A response to Corkeron and Connor. Mar Mamm Sci 17: 432-436

* Clapham PJ, Bérubé M, Mattila DK (1995) Sex ratio of the Gulf of Maine humpback whale population. Mar Mamm Sci 11:227-231

* Connor RC, Corkeron PJ (2001) Predation past and present: killer whales and baleen whale migration. Mar Mamm Sci 17:436-439

* Corkeron PJ, Connor RC (1999) Why do baleen whales migrate? Mar Mamm Sci 15:1228-1245

* Craig AS, Herman L, Pack AA, Waterman JO (2014) Habitat segregation by female humpback whales in Hawaiian waters: avoidance of males? Behaviour 151:613-631

* Dahlheim ME, White PA (2010) Ecological aspects of transient killer whales Orcinus orca as predators in southeastern Alaska. Wildl Biol 16:308-322

*DeMaster DP, Trites AW, Clapham P, Mizroch S, Wade P, Small RJ, Hoef JV (2006) The sequential megafaunal collapse hypothesis: testing with existing data. Prog Oceanogr 68:329-342

Dolphin WF (1987) Observations of humpback whale Megaptera novaeangliae-killer whale Orcinus orca interactions in Alaska: comparison with terrestrial predatorprey relationships. Can Field Nat 101:70-75

Durban JW, Pitman RL (2012) Antarctic killer whales make rapid, round-trip movements to subtropical waters: evidence for physiological maintenance migrations? Biol Lett 8:274-277

Ersts PJ, Rosenbaum HC (2003) Habitat preference reflects social organization of humpback whales (Megaptera novaeangliae) on a wintering ground. J Zool (Lond) 260: 337-345

Félix F, Botero-Acosta N (2011) Distribution and behaviour of humpback whale mother-calf pairs during the breeding season off Ecuador. Mar Ecol Prog Ser 426: $277-287$

Félix F, Guzman HM (2014) Satellite tracking and sighting data analyses of Southeast Pacific humpback whales (Megaptera novaeangliae): Is the migratory route coastal or oceanic? Aquat Mamm 40:329-340

Félix F, Haase B (2001) The humpback whale off the coast of Ecuador, population parameters and behavior. Rev Biol Mar Oceanogr 36:61-74

Félix F, Castro C, Laake J, Haase B, Scheidat M (2011) Abundance and survival estimates of the southeastern Pacific humpback whale stock from 1991-2006 photoidentification surveys in Ecuador. J Cetacean Res Manag 3:301-308

Ferguson SH, Higdon JW, Chmelnitsky EG (2010) The rise of killer whales as a major Arctic predator. In: Ferguson SH, Loseto LL, Mallory ML (eds) A little less Arctic: top predators in the world's largest northern inland sea, Hudson Bay. Springer Science+Business Media B.V., Dordrecht, p 117-136 
Flórez-González L (1991) Humpback whales, Megaptera novaeangliae, in the Gorgona Island, Colombian Pacific breeding waters: population and pod characteristics. Mem Queensl Mus 20:291-295

Flórez-González L, Capella J, Rosenbaum HC (1994) Attack of killer whales (Orcinus orca) on humpback whales (Megaptera novaeangliae) on a South American Pacific breeding ground. Mar Mamm Sci 10:218-222

Ford JKB, Ellis GM, Matkin DR, Balcomb KC, Briggs D, Morton AB (2005) Killer whale attacks on minke whales: prey capture and antipredator tactics. Mar Mamm Sci 21:603-618

Franklin T, Franklin W, Brooks L, Harrison P (2018) Sitespecific female-biased sex ratio of humpback whales during a stopover early in the southern migration. Can J Zool 96:533-544

* Garcia-Godos I (2004) Killer whale (Orcinus orca) occurrence off Peru, 1995-2003. Latin Am J Aquat Mamm 3:177-180

Gibbons J, Capella J, Valladares C (2003) Rediscovery of a humpback whale, Megaptera novaeangliae, feeding ground in the Straits of Magellan, Chile. J Cetacean Res Manag 5:203-208

* Guerrero-Ruiz M, García-Godos I, Urbán J (2005) Photographic match of a killer whale (Orcinus orca) between Peruvian and Mexican waters. Aquat Mamm 31:438-441

Guzman HM, Félix F (2017) Movements and habitat use by Southeast Pacific humpback whales satellite tracked at two breeding sites. Aquat Mamm 43:139-155

Guzman HM, Condit R, Pérez-Ortega B, Capella JJ, Stevick $P$ (2015) Population size and migratory connectivity of humpback whales wintering in Las Perlas Archipelago, Panama. Mar Mamm Sci 31:90-105

*Häussermann V, Acevedo J, Försterra G, Bailey M, AguayoLobo A (2013) Killer whales in Chilean Patagonia: additional sightings, behavioural observations, and individual identifications. Rev Biol Mar Oceanogr 48:73-85

* Hucke-Gaete R, Haro D, Torres-Florez JP, Montecinos Y and others (2013) A historical feeding ground for humpback whales in the Eastern South Pacific revisited: the case of northern Patagonia, Chile. Aquat Conserv 23:858-867

International Whaling Commission (2006) Report of the Scientific Committee. Annex H. Report of the Sub-Committee on the other southern hemisphere whale stocks. J Cetacean Res Manag 8(Suppl):151-170

Jefferson TA, Stacey PJ, Baird RW (1991) A review of killer whale interactions with other marine mammals: predation to co-existence. Mammal Rev 21:151-180

Katona S, Whitehead H (1981) Identifying humpback whales using their natural markings. Polar Rec 20:439-444

Matkin DR, Straley JM, Gabriele CM (2007) Killer whale feeding ecology and non-predatory interactions with other marine mammals in the Glacier Bay region of Alaska. In: Piatt JF, Gende SM (eds) Proc 4th Glacier Bay Science Symposium. US Geological Survey, Anchorage, AK, p 155-158

McCordic JA, Todd SK, Stevick PT (2014) Differential rates of killer whale attacks on humpback whales in the North Atlantic as determined by scarification. J Mar Biol Assoc UK 94:1311-1315

McCullagh P, Nelder JA (1989) Generalized linear models, 2nd edn. Monographs on statistics and applied probability. Chapman and Hall/CRC, Boca Raton, FL

Mehta AV, Allen JM, Constantine R, Garrigue C and others (2007) Baleen whales are not important as prey for killer whales Orcinus orca in high-latitude regions. Mar Ecol
Prog Ser 348:297-307

Mizroch SA, Rice DW (2006) Have North Pacific killer whales switched prey species in response to depletion of the great whale populations? Mar Ecol Prog Ser 310:235-246

*Morisaka T, Connor RC (2007) Predation by killer whales (Orcinus orca) and the evolution of whistle loss and narrow band high frequency clicks in odontocetes. J Evol Biol 20:1439-1458

Naessig PJ, Lanyon JM (2004) Levels and probable origin of predatory scarring on humpback whales (Megaptera novaeangliae) in east Australian waters. Wildl Res 31: 163-170

*Pacheco AS, Silva S, Alcorta B (2009) Winter distribution and group composition of humpback whales (Megaptera novaeangliae) off Northern Peru. Latin Am J Aquat Mamm 7:33-38

Pitman RL, Durban JW (2012) Cooperative hunting behavior, prey selectivity and prey handling by pack ice killer whales (Orcinus orca), type B, in Antarctic Peninsula waters. Mar Mamm Sci 28:16-36

* Pitman RL, Totterdell JA, Fearnbach H, Ballance LT, Durban JW, Kemps H (2015) Whale killers: prevalence and ecological implications of killer whale predation on humpback whale calves off Western Australia. Mar Mamm Sci 31:629-657

* Pitman RL, Deecke VB, Gabriele CM, Srinivasan M and others (2017) Humpback whales interfering when mammal eating killer whales attack other species: mobbing behavior and interspecific altruism? Mar Mamm Sci 33: 7-58

R Core Team (2015) R: a language and environment for statistical computing. R Foundation for Statistical Computing, Vienna. www.r-project.org

Rasmussen K, Palacios D, Calambokidis J, Saborío MT and others (2007) Southern Hemisphere humpback whales wintering off Central America: insights from water temperature into the longest mammalian migration. Biol Lett 3:302-305

Reeves RR, Berger J, Clapham PJ (2006) Killer whales as predators of large baleen whales and sperm whales. In: Estes JA, DeMaster DP, Doak DF, Williams TM, Brownell RL Jr (eds) Whales, whaling and ecosystems. University of Chicago Press, Chicago, IL, p 174-187

Reinhart NR, Ferguson SH, Koski WR, Higdon JW, LeBlanc B, Tervo O, Jepson PD (2013) Occurrence of killer whale Orcinus orca rake marks on eastern Canada-West Greenland bowhead whales Balaena mysticetus. Polar Biol 36: 1133-1146

Sabaj V, Vilina V, Guerrero S, Capella J, Gibbons J, Valladares C (2004) Genetic structure of the recently discovered feeding ground of humpback whales at Straits of Magellan, Chile. Report SC/56/SH19 to the Scientific Committee of the 56th Annual Meeting of the International Whaling Commission, Italy. IWC, Cambridge

Scheidat M, Castro C, Denkinger J, González J, Adelung D (2000) A breeding area for humpback whales (Megaptera novaeangliae) off Ecuador. J Cetacean Res Manag 2:165-172

* Springer AM, Estes JA, Van Vliet GB, Williams TM, Doak DF, Danner EM, Pfister B (2003) Sequential megafaunal collapse in the North Pacific Ocean: an ongoing legacy of industrial whaling? Proc Natl Acad Sci USA 100: 12223-12228

Steiger GH, Calambokidis J, Straley JM, Herman LM and others (2008) Geographic variation in killer whale attacks 
on humpback whales in the North Pacific: implications for predation pressure. Endang Species Res 4:247-256

Stevick ST, Aguayo A, Allen J, Avila IC and others (2004) Migration of individually identified humpback whales between the Antarctic Peninsula and South America. J Cetacean Res Manag 6:109-113

Trites AW, Deecke VB, Gregr EJ, Ford JK, Olesiuk PF (2007) Killer whales, whaling, and sequential megafaunal collapse in the North Pacific: a comparative analysis of the dynamics of marine mammals in Alaska and British

Editorial responsibility: Ana Cañadas, Madrid, Spain
Columbia following commercial whaling. Mar Mamm Sci 23:751-765

* Wade PR, Burkanov VN, Dahlheim ME, Friday NA, Fritz LW, Loughlin TR, Clapham PJ (2007) Killer whales and marine mammal trends in the North Pacific: a reexamination of evidence for sequential megafauna collapse and the prey-switching hypothesis. Mar Mamm Sci 23:766-802

* Whitehead H, Glass C (1985) Orcas (killer whales) attack humpback whales. J Mammal 66:183-185

Submitted: February 7, 2018; Accepted: September 19, 2018 Proofs received from author(s): October 16, 2018 